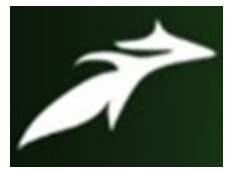

Gaurav Mishra et al, International Journal of Advances in Agricultural Science and Technology,

Vol.8 Issue.9, September-2021, pg. 61-69

ISSN: 2348-1358

Impact Factor: 6.057

NAAS Rating: 3.77

\title{
ADOPTION BEHAVIOUR OF FARMERS TOWARDS WHEAT VARIETY SHUATS W-6, IN HOLAGARH BLOCK OF PRAYAGRAJ DISTRICT, UTTAR PRADESH
}

\author{
Gaurav Mishra ${ }^{1}$; Syed H. Mazhar ${ }^{2}$; Jahanara ${ }^{3}$ \\ ${ }^{1}$ M.Sc. Ag. (Agricultural Extension and Communication), SHUATS (Prayagraj) \\ ${ }^{2}$ Professor (Agricultural Extension and Communication), SHUATS (Prayagraj) \\ ${ }^{3}$ Head, Department of Agriculture Extension and Communication, SHUATS (Prayagraj) \\ Author's e-mail: gaurav.m80501@gmail.com \\ DOI: 10.47856/ijaast.2021.v08i9.008
}

Abstract: India is an agrarian based country with two third of population as farming community. Wheat, 'King of cereals' also the second most cultivated food crop has technological gap in adoption of improved variety, hence the present study aims to understand the socio-economic profile, knowledge, attitude and adoption level of respondents to identify the technological gap and increase the adoption rate. The present study is carried out with 120 respondents from ten villages of Holgarh block of Prayagraj district of Uttar Pradesh. Primary data collected with the help of semi-structured interview schedule and subjected to statistical analysis. The results indicated that majority of the wheat growers had medium level of knowledge, attitude and adoption towards SHUATS W-6 variety. Further, it was recommended for timely availability of seeds, fertilizer, proper marketing facility and reducing the cost of critical inputs.

Keywords: Wheat growers, SHUATS, Knowledge, Attitude, Adoption.

\section{Introduction}

Agriculture is the predominant sector of Indian economy and contributes 18 per cent to GDP. Wheat (Triticum aestivum) the world's largest cereal crop belongs to Graminae (Poaceae) family of the genus Triticum. It has been described as the "King of cereals" because of the acreage it occupies, high productivity and the prominent position in the international food grain trade (Anveshaet al. 2020). Wheat is the second most important food crop of the India which contributes nearly one-third of the total food grains production. About 84.00 per cent of the total 


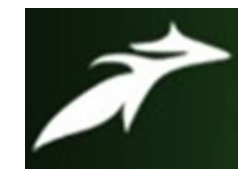

Gaurav Mishra et al, International Journal of Advances in Agricultural Science and Technology, Vol.8 Issue.9, September-2021, pg. 61-69

ISSN: $2348-1358$

Impact Factor: 6.057

NAAS Rating: 3.77

production of wheat is confined to Uttar Pradesh, Punjab, Madhya Pradesh, Rajasthan, Haryana and Bihar. The average yield of wheat in India is $2.87 \mathrm{t} / \mathrm{ha}$ which is very low as compared to other countries. Wheat is the most extensively grown cereal crop in the world, covering about 237 million hectares annually, and accounting for a total of 420 million tones.

Target for wheat output has been kept at 106.5 million tonnes, same at the current level estimated for the 2019-20 crop year. Uttar Pradesh is the largest state with maximum contribution towards national production (35.03\%) from a large area (35.12 \%), but with productivity on a lower side of 2.7 tonnes/ha. (Anvesha et al. 2020). Uttar Pradesh has registered the highest-ever wheat produce in the year 2017-18, revealed officials in the agriculture department. The wheat production data of agricultural directorate shows that in the year 2017-18 total production was 357.19 lakh MT which indicated 7.50 lakh MT more than the production of previous year.

The credit of the record production and productivity goes to continuous Government efforts, balanced monsoon as well as creating awareness and advanced scientific production practices among the farmers with a target to double the income of the farmers by 2022 (Parashar 2018). The production of wheat in Prayagraj is 469115 MT. (Contingency plan of Prayagraj District). The productivity of wheat in Prayagraj is 22.19 q/ha (Contingency plan of Prayagraj District).

Vipin (2011) stated that most of the wheat growers were middle aged, had middle school, small farmers, medium level of social participation, medium level of socio-economic status, medium level of attitude, medium level of mass media exposure, risk preference; medium and high level of innovativeness with medium level of knowledge on wheat cultivation practices. Raghuwanshi (2012) reported that in case of (beneficiaries) wheat growers, the majority of respondents had medium and high level of adoption in respect of wheat production technology. 


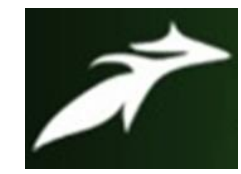

Gaurav Mishra et al, International Journal of Advances in Agricultural Science and Technology, Vol.8 Issue.9, September-2021, pg. 61-69

ISSN: 2348-1358

Impact Factor: 6.057

NAAS Rating: 3.77

Mohanty et al., (2013) revealed that highest proportion of the respondents were in young age group.

Rahman(2013) reported a positively and significantly correlated between adoption level of the respondents about selected wheat production technologies and the independent variables like education, farm experience and extension contact. Kant et.al., (2013) reported that majority of the wheat growers exhibited a medium level of adoption category. Wadge (2017) revealed that independent variables, namely, farming experience, education, extension contact and risk orientation had positively and significantly correlated with the adoption level; whereas, farming experience, education, social participation and risk orientation status had significant effect on adoption level of the respondents about kharif maize production technology.

Karangami (2017) revealed that three-fourth of the respondents had medium knowledge level. Whereas, Patodiya (2018) reported that nearly two-third per cent of the respondents had medium knowledge level about scientific wheat cultivation practices. Bose et al.,(2019) reported that socio-economic characteristics of the sample group were medium level with medium level of adoption. Smriti et.al., (2020) reported that regarding financial constraint, unregulated marketing facility was perceived as the major constraint, followed by high cost of wages, high cost of chemicals and equipments, less risk bearing capacity of farmers and enhanced labor wage rates. With respect to administrative constraints, lack of technical knowhow of the staff was perceived as important constraint followed by irregular visits of the staff during crop season, barriers in the distribution of required varieties and seed and inefficient extension workers.

\section{Research Methodology}

For present study, descriptive research design is adopted. Prayagraj district of Uttar Pradesh is selected by purposive sampling since maximum farmers produce wheat crop. Out of 20 blocks in Prayagraj district of Uttar Pradesh, Holagarh block of Soraon tehsil has been selected by purposive sampling because most of the farmers are adopting SHUATS W-6 variety 


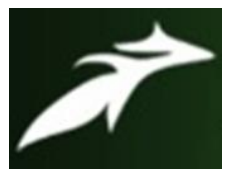

Gaurav Mishra et al, International Journal of Advances in Agricultural Science and Technology, Vol.8 Issue.9, September-2021, pg. 61-69

ISSN: 2348-1358

Impact Factor: 6.057

NAAS Rating: 3.77

cultivation. Among 92 villages of Holagarh, 10 villages were selected purposively based on the maximum area covered under SHUATS W-6 variety. From each village, 12 respondents will be selected. Thus from the selected 10 villages, 120 respondents will be selected randomly for the study. The primary data were collected with the help of interview schedule and the responses were recorded, classified and tabulated and appropriate statistical tools were employed.

\section{Results and Discussion}

The socio-economic profile of the respondents was studied under various characteristics and the results were presented under table.1.

Table.1. Socio-economic profile of the respondents $(n=120)$

\begin{tabular}{|c|c|c|c|c|}
\hline S. No. & Characteristics & Category & Frequency & Percentage \\
\hline \multirow[t]{3}{*}{1} & \multirow[t]{3}{*}{ Age (in years) } & Young $(<35)$ & 40 & 33.30 \\
\hline & & Middle(36-55) & 46 & 38.40 \\
\hline & & Old $(>55)$ & 34 & 28.30 \\
\hline \multirow[t]{7}{*}{2} & \multirow[t]{7}{*}{ Education } & Illiterate & 25 & 20.83 \\
\hline & & Literate (can read only) & 18 & 15.00 \\
\hline & & Primary school & 20 & 16.66 \\
\hline & & Middle school & 7 & 5.83 \\
\hline & & High school & 18 & 15.00 \\
\hline & & Intermediate & 22 & 18.33 \\
\hline & & Graduate and above & 8 & 6.67 \\
\hline \multirow[t]{3}{*}{3} & \multirow{3}{*}{$\begin{array}{c}\text { Communication media } \\
\text { exposure }\end{array}$} & Low & 51 & 42.50 \\
\hline & & Medium & 57 & 47.50 \\
\hline & & High & 12 & 10.00 \\
\hline \multirow[t]{2}{*}{4} & \multirow[t]{2}{*}{ Working experience } & Less than 3 years & 30 & 25.00 \\
\hline & & $3-10$ years & 65 & 55.00 \\
\hline
\end{tabular}




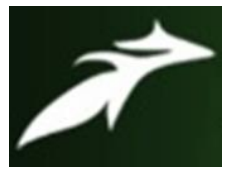

Gaurav Mishra et al, International Journal of Advances in Agricultural Science and Technology, Vol.8 Issue.9, September-2021, pg. 61-69

ISSN: 2348-1358

Impact Factor: 6.057

NAAS Rating: 3.77

\begin{tabular}{|c|c|c|c|c|}
\hline & & More than 10 years & 24 & 20.00 \\
\hline \multirow[t]{3}{*}{5} & \multirow[t]{3}{*}{ Family size } & Small & 34 & 28.33 \\
\hline & & Medium & 57 & 47.50 \\
\hline & & Large & 29 & 24.17 \\
\hline \multirow[t]{3}{*}{6} & \multirow[t]{3}{*}{ Land holding } & Marginal farmer (Less than ha) & 30 & 25.00 \\
\hline & & Small farmer (1-2 ha) & 65 & 55.00 \\
\hline & & Large farmer (2-3 ha) & 24 & 20.00 \\
\hline \multirow[t]{3}{*}{7} & \multirow[t]{3}{*}{ Annual income } & Low (upto 50,000) & 14 & 11.70 \\
\hline & & Medium (50,000 - 1 lakh) & 98 & 81.70 \\
\hline & & High ( above 1 lakh) & 8 & 6.60 \\
\hline \multirow[t]{3}{*}{8} & \multirow[t]{3}{*}{ Mass media exposure } & Low & 35 & 29.17 \\
\hline & & Medium & 73 & 60.83 \\
\hline & & High & 12 & 10.00 \\
\hline \multirow[t]{3}{*}{9} & \multirow[t]{3}{*}{ Leadership capacity } & Low & 29 & 24.17 \\
\hline & & Medium & 77 & 64.17 \\
\hline & & High & 14 & 11.67 \\
\hline \multirow[t]{3}{*}{10} & \multirow[t]{3}{*}{ Social participation } & Low & 21 & 17.50 \\
\hline & & Medium & 59 & 49.17 \\
\hline & & High & 38 & 31.67 \\
\hline
\end{tabular}

From table.1, it can be interpreted that majority of the respondents were middle aged (38.40\%), followed by young aged (33.30\%) and old aged people (28.30\%). Most of the respondents were illiterate $(20.83 \%)$, followed by intermediate level $(18.33 \%)$, primary school (16.67\%), an equal percentage of respondents were literate (can read only) (15\%) and high school $(15 \%)$, graduate $(6.67 \%)$, middle school $(5.83 \%)$ and only 1.67 per cent of respondents had post-graduate level of education. Less than half of the respondents had medium level of family size (47.50\%), followed by small sized family (28.33\%) and large sized family (24.17\%). 


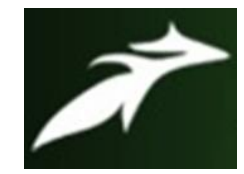

Gaurav Mishra et al, International Journal of Advances in Agricultural Science and Technology, Vol.8 Issue.9, September-2021, pg. 61-69

ISSN: 2348-1358

Impact Factor: 6.057

NAAS Rating: 3.77

More than three-fourth of the respondents earns medium level of annual income (81.70\%), followed by low (11.70\%) and high (6.60\%) level of annual income. Less than two-third of the respondents had medium level of mass media exposure $(60.83 \%)$, followed by low $(29.17 \%)$ and high level of mass media exposure $(10 \%)$.

Meanwhile, more than half of the respondents were small farmer (1-2 ha) (55\%), followed by small farmer (less than $1 \mathrm{ha}$ ) (25\%) and remaining 20 per cent of respondents were large farmer (2-3 ha). Majority of the respondents had medium level of leadership capacity (64.17\%), followed by low (24.17\%) and high (11.67\%) level of leadership capacity. Nearly half of the respondents $(49.17 \%)$ had medium level of social participation, followed by high $(31.67 \%)$ and low $(17.50 \%)$ level of social participation. More than half of the respondents had 3-10 years working experience (55\%), followed by less than 3 years working experience $(25 \%)$ and only 20 per cent had more than 10 years of working experience. Majority of the respondents had medium level of communication media exposure (47.50\%), followed by low level (42.50\%) and low $(10 \%)$ level of communication media exposure.

The knowledge level of respondents towards SHUATS W-6 wheat variety is tabulated and presented in table.15 and fig. 15.

Table.2. Knowledge of respondents towards improved SHUATS W-6 wheat variety

$(\mathbf{n}=120)$

\begin{tabular}{|c|c|c|c|}
\hline S. No. & Knowledge level & Frequency & Percentage \\
\hline 1 & Low & 39 & 32.50 \\
\hline 2 & Medium & 51 & 42.50 \\
\hline 3 & High & 30 & 25.00 \\
\hline
\end{tabular}

From table.2, it was reported that most of the respondents $(42.50 \%)$ had medium level of knowledge, followed by low (32.50\%) and high level of knowledge (25\%) 


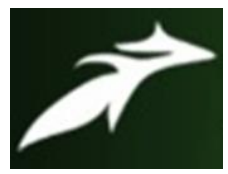

Gaurav Mishra et al, International Journal of Advances in Agricultural Science and Technology, Vol.8 Issue.9, September-2021, pg. 61-69

ISSN: 2348-1358

Impact Factor: 6.057

NAAS Rating: 3.77

The attitude level of respondents towards SHUATS W-6 wheat variety is tabulated and presented in table.16 and fig. 16.

Table.3. Attitude level of respondents towards improved SHUATS W-6 wheat variety

$(\mathbf{n}=\mathbf{1 2 0})$

\begin{tabular}{|c|c|c|c|}
\hline S. No. & Attitude level & Frequency & Percentage \\
\hline 1 & Low & 26 & 21.67 \\
\hline 2 & Medium & 59 & 49.17 \\
\hline 3 & High & 35 & 29.17 \\
\hline
\end{tabular}

From table.3, it was reported that nearly half of the respondents had medium level of attitude (49.17\%), high level of attitude (29.17\%) and medium level of attitude (21.67\%) towards improved SHUATS w-6 variety.

The adoption level of respondents towards SHUATS W-6 wheat variety is tabulated and presented in table. 4 and fig. 4 .

Table.4. Adoption of respondents towards improved SHUATS W-6 wheat variety

$(\mathbf{n}=120)$

\begin{tabular}{|c|c|c|c|}
\hline S. No. & Adoption level & Frequency & Percentage \\
\hline 1 & Low & 34 & 28.33 \\
\hline 2 & Medium & 57 & 47.50 \\
\hline 3 & High & 29 & 24.17 \\
\hline
\end{tabular}

From table.4, it was reported that nearly half of the respondents had medium level of adoption (47.50\%), followed by low (28.33\%) and high level of adoption $(24.17 \%)$ towards SHUATS W-6 variety. 


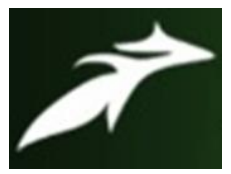

Gaurav Mishra et al, International Journal of Advances in Agricultural Science and Technology, Vol.8 Issue.9, September-2021, pg. 61-69

ISSN: 2348-1358

Impact Factor: 6.057

NAAS Rating: 3.77

\section{Conclusion}

From the study it can be understand that majority of the respondents were middle aged, illiterate, had medium level of family size, earns medium level of annual income, had medium level of mass media exposure, small farmer (1-2 ha), medium level of leadership capacity, medium level of social participation, medium level of working experience and medium level of communication media exposure with medium level of knowledge, attitude and adoption. Thus, it was recommended that full time electricity should be provided at the time of irrigation and made it priority suggestion, credit should be available easily at low interest rate, improved seed should be available in time, irrigation facilities should be available in time, training camps regarding technical knowledge should be organized time to time, knowledge regarding plant protection should available in time, fertilizer availability should be in time, field visit should be made regularly by extension workers and agricultural officers.

\section{REFERENCES}

[1]. Bose, D.K., Maurya, O.P. and Rai, A.K. (2019) Adoption behaviour of farmers about recommended wheat production practices in Prayagraj district of Uttar Pradesh. International Journal of Innovation Science and Research Technology, vol-4, issue-9; 2456-2165.

[2]. Karangami, R. (2017). Adoption of recommended rice cultivation practices by the farmers from Palghar district. Doctoral dissertation, DBSKKV, Dapoli.

[3]. Kant , K., Khan, N., Meena, D.K and Iqwal, M. S. ( 2013) Study of adoption behavior of wheat growers in Bedar district of India.Indian Journal of Agric. Research, 47(2):173-177

[4]. Mohanty, A. K, Lepch, B.L. and Kumar Ashok (2013) Constraints analysis in adoption of vegetable production technologies for livelihood perspective of tribal farmers North Sikkim, Indian Research Journal Extension Education 13(2): 51-56.

[5]. Patodiya, R. S. (2018). Knowledge and adoption of scientific wheat cultivation practices in Rajasthan. Indian Research Journal of Extension Education. 18(1):93-95.

[6]. Raghuwanshi, Rajeev (2012) Impact of Farmer field school (F.F.S.) on Knowledge and adoption level of wheat crop in Sanwer block of Indore district Madhya Pradesh M.Sc. ag thesis submitted to the Rajmata VijayarajeScindia Krishi Vidyalaya, Gwalior.

[7]. Rahman, M. S. and Haque, Z. (2013). Adoption of selected wheat production technologies in two northern districts of Bangladesh. International Journal of Agricultural Research, Innovation and Technology.3 (1): 5-11. 


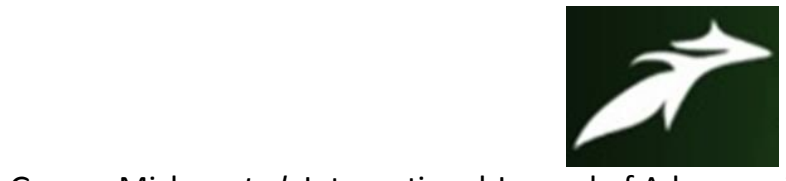

Gaurav Mishra et al, International Journal of Advances in Agricultural Science and Technology,

Vol.8 Issue.9, September-2021, pg. 61-69

ISSN: 2348-1358

Impact Factor: 6.057

NAAS Rating: 3.77

[8]. Smirit singh, Anuj TIwari and Singh Ratan, R.P. 2020. Constraints perceived by wheat growers in sitapur district of Uttar Pradesh. Journal of Krishi Vigyan. 8(2):49-53.

[9]. Vipin Kumar Gupta. 2011. A study on knowledge and adoption behaviour of irrigated wheat growers in Ichhawer block of Sehore District, Madhya Pradesh. M.Sc., Thesis. RVSKVV, Gwalior.

[10]. Wadge, S. K. (2017). Knowledge and adoption of kharif maize production technology among the growers. Doctoral dissertation, Vasantrao Naik Marathwada Krishi Vidyapeeth, Parbhani. 